\title{
SOIL DEVELOPMENT ON PROTEROZOIC AND PALEOZOIC ROCKS OF CENTRAL BOHEMIA
}

\author{
Anna ŽIGOVÁ *, Martin ŠŤASTNÝ and Petr MIKYSEK \\ Institute of Geology of the Czech Academy of Sciences, Rozvojová 269, 16500 Praha 6-Lysolaje \\ *Corresponding author's e-mail: zigova@gli.cas.cz
}

\section{ARTICLE INFO \\ Article history: \\ Keywords: \\ Granite \\ Greywacke \\ Mudstone \\ Leptosols \\ Clay minerals \\ Weddellite \\ Whewellite}

Received 6 May 2021

Accepted 28 July 2021

Available online 26 August 2021

\section{ABSTRACT}

The character of modern pedogenesis in the territory of the Brdská and Křivoklátská vrchovina Highlands was studied on silicate rocks such as Paleozoic granite and Proterozoic mudstone and greywacke. The parent materials were evaluated on the basis of petrography, X-ray diffractometry of powder samples of rock forming and heavy minerals. The soils were described as for their macromorphological characterics and the results of a variety of analyses of organic and anorganic components. Pedogenesis proceeded in acid conditions. The values of base saturation are mostly below $50 \%$ for the Ah horizons. The intensity of soil development on individual parent material decreases in the order: mudstone (Ah-AhBw-Bw-C) $>$ granite (Oi-Oe-Oa-Ah-Bw-C) $>$ greywacke 1 (Oi-Oe-Oa-Ah-AhC-C) $>$ greywacke 2 (Oi-Oe-Oa-Ah-C). The process of humification was documented at all study sites. Evidence of pedogenetic alteration is present in soils developed on granite and mudstone. High amounts of chlorite and elevated contents of illite are characteristic for Cambic Leptosols (Dystric, Skeletic) on mudstone. Weddellite and whewellite were found in relatively large amounts in O horizons of soils except for the Červený kríž site. The predominant from of calcium oxalate minerals at these sites is whewellite. Weddellite occurs in small amount, which is probably due to its lower stability.

\section{INRODUCTION}

Soils developed on Proterozoic and Paleozoic rocks occur in different ecological conditions in the territory of the Czech Republic. Such soils mostly belong within the groups of Leptosols and Cambisols. These are widely distributed in various regional units of the structure of soil cover of the Czech Republic (Němeček and Tomášek, 1983).

Targulian and Krasilnikov (2007) postulated that pedogenesis is limited by the reserves of certain components in parent materials. These reserves vary within individual rock types. West et al. (2005) showed that the weathering rate of a mineral or rock decreases with the time and that silicate weathering rates are governed by no single parameter but require a consideration in multiple dimensions. The early stages of pedogenesis are connected, besides weathering of rocks, with plant biomass. Waren (2017) examined how the pool of small organic $\mathrm{N}$ compounds varies during the soil development. Differences in the contents of organic $\mathrm{N}$ were found among profiles of different ages, but these differences were not related to the age or the build-up of recalcitrant compounds over time.

Information about the interaction between weathering of rocks and subsequent soil devevelopment has been described from different regions but concentrates exclusively on some rocks. Lessovaia and Polekhovsky (2009) characterized Holocene pedogenesis on different types of amphibolites, metamorphosed gabbro-diabases and serpentinous dunite. The relation between weathering and soil formation on granite and granodiorite was investigated in Switzerland (Marvis et al., 2010). Papers from Poland include a study of soil development on granodiorites (Weber et al., 2012) and a study of pedogenesis on quartzite and schists (Loba et al., 2020).

The main object of this study is to determine individual stages soil profile development on Proterozoic and Paleozoic rocks of central Bohemia in the territory of the Brdská and Křivoklátská vrchovina Highlands and characterize the relationship between the type of parent material and the mineral composition of soils.

\section{GEOLOGY OF BEDROCK}

Proterozoic area of central Bohemia and its closests surroundigs was selected for the study of pedogenesis. The Central Bohemian region, also called Bohemicum (Malkovský, 1979), is a unit also known as the Teplá-Barrandian region (Mašek, 2000; 


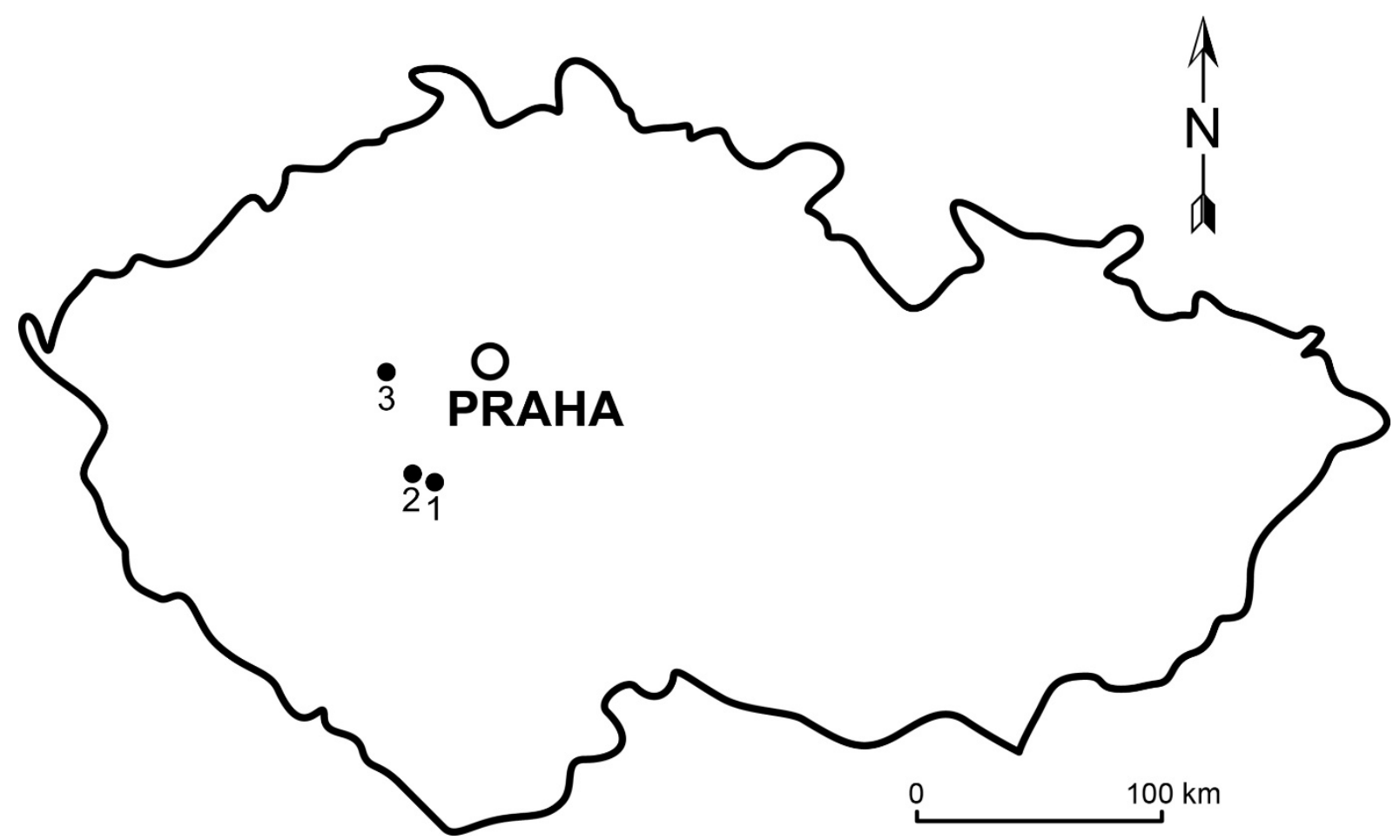

Fig. 1 Locations of the studied sites. 1 - Bytíz, 2 - Lhota u Př́ibramě, 3 - Červený kř́iž.

Hajná et al., 2011), and lies in the centre of the Bohemian Massif. Bohemicum is the best preserved fragment of the Cadomian orogeny in central Europe (Franke, 2000). It has the form of a belt of folded Proterozoic rocks, unconformably overlain by unmetamorhosed Lower Paleozoic rocks (Cambrian to Devonian) in a typical synclinal structure referred to as the Barrandian (Vorel and Stárková, 2011). Metamorphic grade gradually increases towards the west and northwest. Metamorphism affected peripheral parts of this unit adjacent to the surroundig units or to bodies of Variscan granitoids. A large part of the Bohemicum consists of Proterozoic sediments up to $10 \mathrm{~km}$ thick. These sediments consist mainly of shales, siltstones and greywackes (Vorel and Stárková, 2011). The Proterozoic is divided into the KralupyZbraslav and Štěchovice groups (Chaloupský et al., 1995; Chlupáč et al., 2002; Kachlík and Chlupáč, 2001). The central and western parts of the area belong to the Kralupy-Zbraslav Group, transected by several belts of basalt, striking roughly west-east. The highest grade of metamorphism was reached at the border of Bohemicum and Moldanubicum. Relicts of Proterozoic of the Teplá-Barrandian area and Early Paleozoic units are also preserved in the envelope of the Central Bohemian pluton in the so-called Islet Zone, specifically in the Rožmitál Block. The outcrops are formed by crystalline complex of amphibolites, locally eclogites, gneisses and migmatites.

\section{MATERIAL AND METHODS}

The research was performed in Proterozoic and Paleozoic rocks of central Bohemia.The positions of studied sites are presented in Figure 1. The Bytíz profile (Fig. 2) is located at the boundary between the Proterozoic rocks and the Central Bohemian pluton. Parent material is granite. The Červený kř́ž profile (Fig. 3) is represented by mudstone of the KralupyZbraslav Group of the Bohemicum as the parent material. The sites of Lhota u Příbramě 1 (Fig. 4) and Lhota u Př́bramě 2 (Fig. 5) are situated in the Rožmitál Metamorphic Islet of the Bohemicum. Parent material is greywacke.

Information about GPS coordinates, altitudes and vegetation of individual soil profiles is sumarized in Table 1. Positions of the soil profiles were determined by GARMIN eTrex Summit in the WGS 84 system.

According to Bína and Demek (2012), the sites of Bytíz, Lhota u Příbramě 1 and Lhota u Príbramě 2 lie within the Brdská vrchovina Highland. The Červený kříž site is a nature reserve and belongs to the Křivoklátská vrchovina Highland.

Climatic conditions were characterized by Quitt (1971). Climate of the Bytíz, Lhota u Příbramě 1 and Lhota u Př́ibramě 2 localities corresponds to a moderately warm region MW5 (140-160 days with mean temperature of $\geq 10{ }^{\circ} \mathrm{C}, 100-120$ days with precipitations $\geq 1 \mathrm{~mm}$ and $60-100$ days with snow cover). Climatic conditions of the Červený krŕž locality correspond to a moderately warm region MW11 (140-160 days with mean temperature of $\geq 10{ }^{\circ} \mathrm{C}, 80-100$ days with precipitations $\geq 1 \mathrm{~mm}$ and 50-60 days with snow cover).

Typical profiles were chosen based on a soil survey with a single gouge auger. All soil profiles 


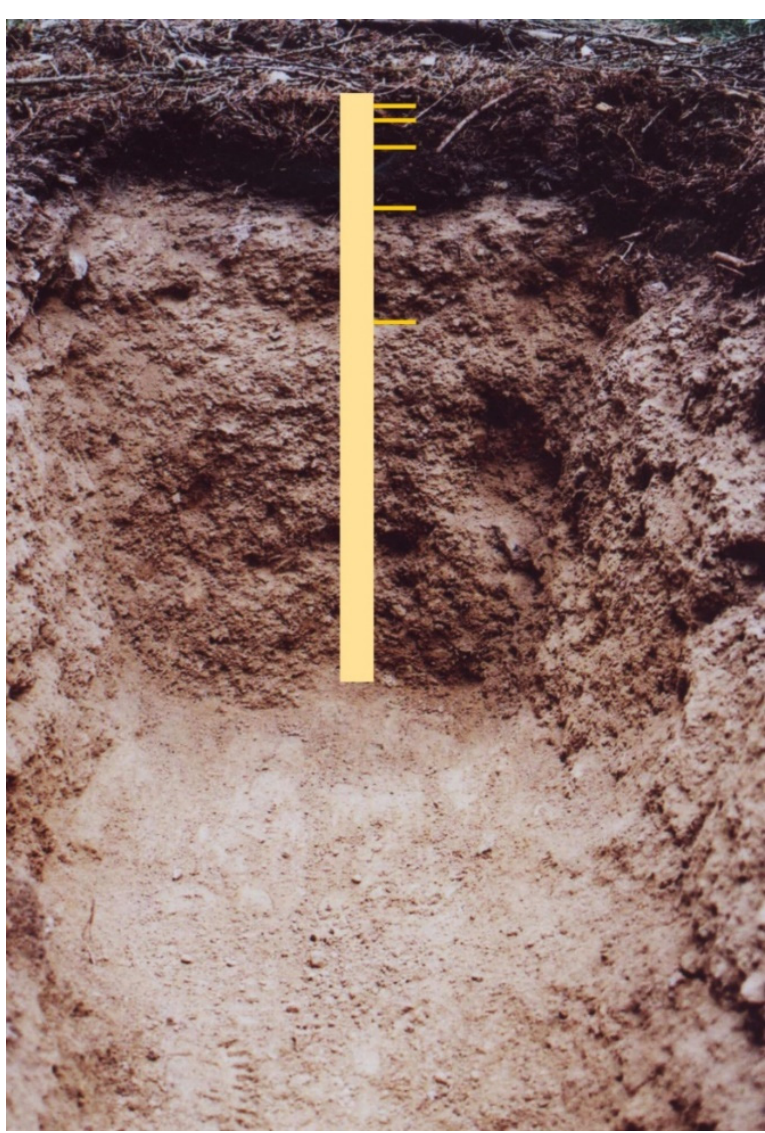

Fig. 2 Cambic Leptosols (Dystric, Skeletic) on granite from the Bytíz site (photo by A. Žigová).

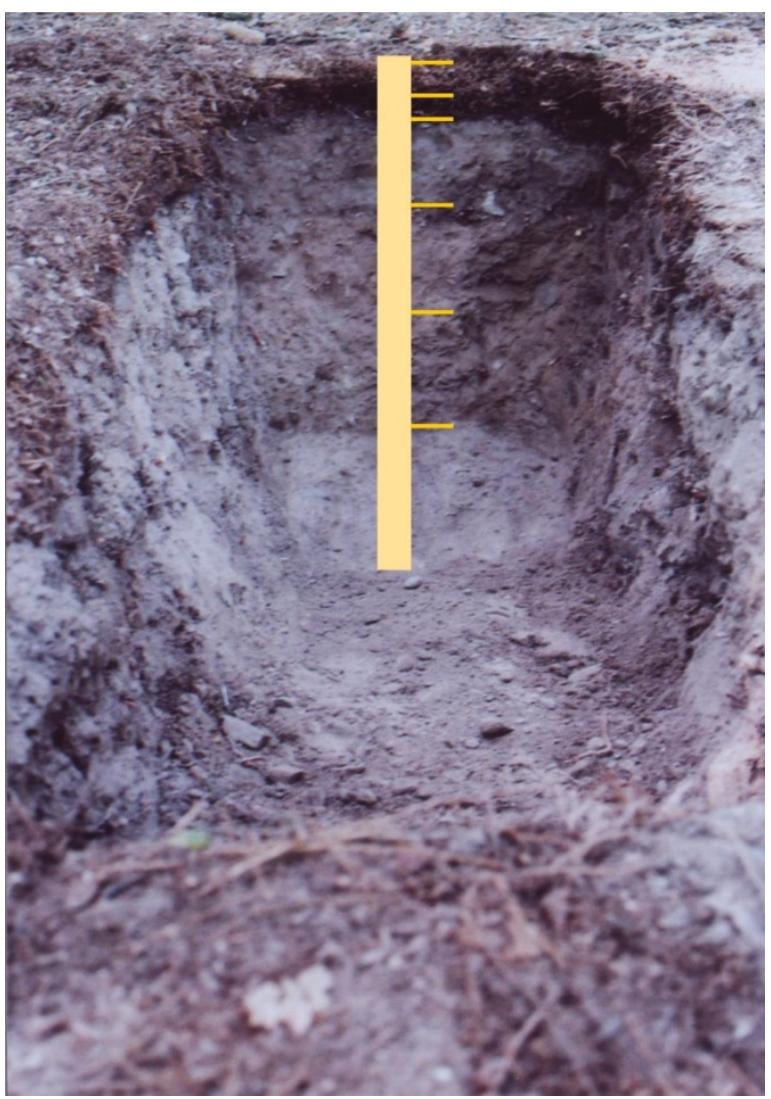

Fig. 4 Dystric Leptosols (Skeletic) on greywacke from the Lhota u Př́bramě 1 site (photo by A. Žigová).

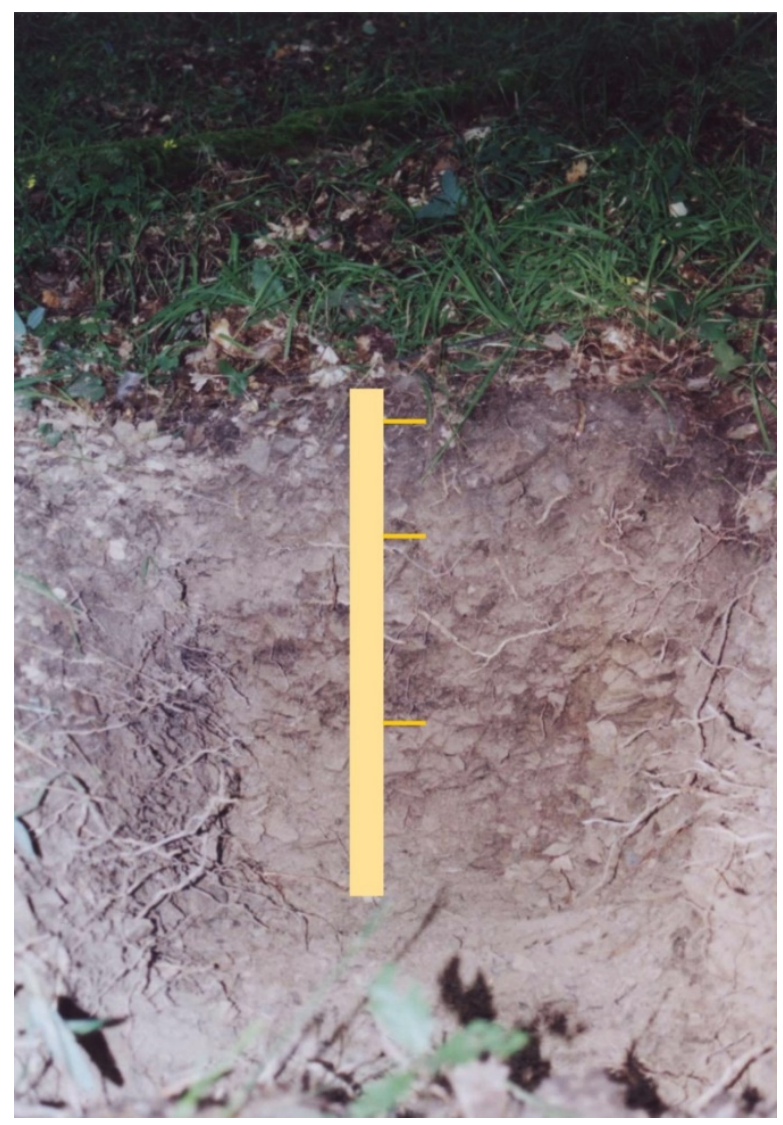

Fig. 3 Cambic Leptosols (Dystric, Skeletic) on mudstone from the Červený kříz site (photo by A. Žigová).

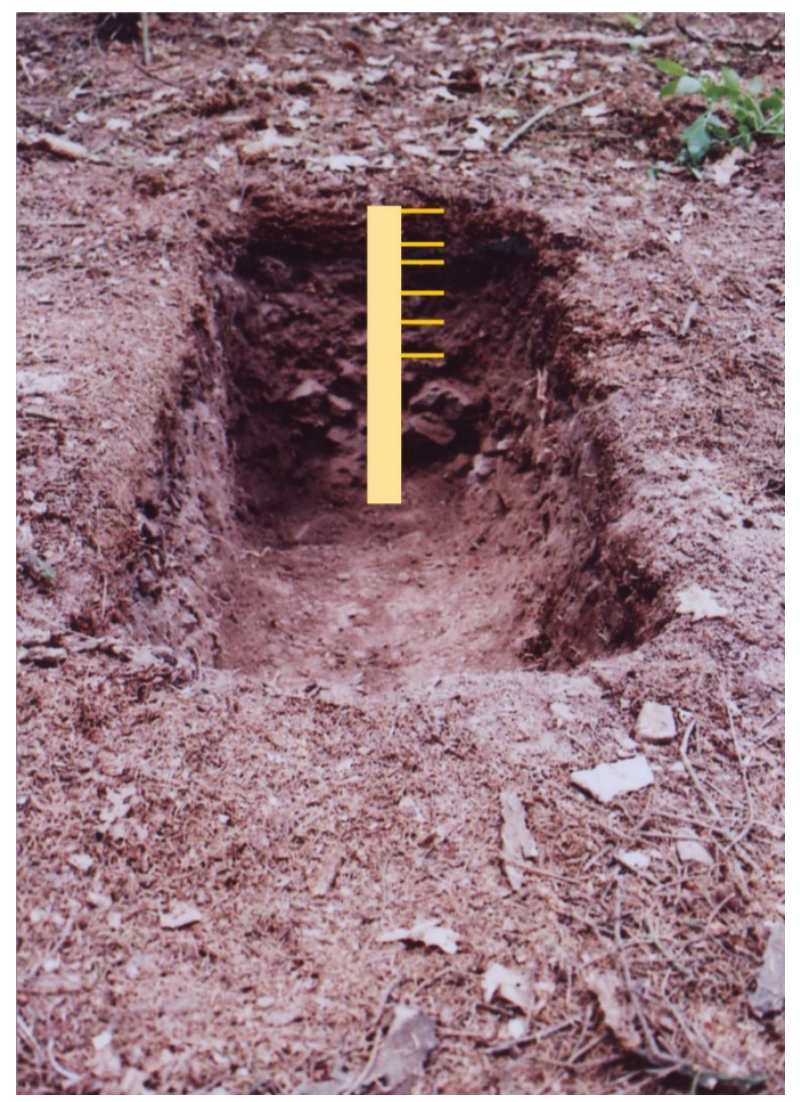

Fig. 5 Dystric Leptosols (Skeletic) on greywacke from the Lhota u Př́bramě 2 site (photo by A. Žigová). 
Table 1 Basic information on the studied sites.

\begin{tabular}{lcccl}
\hline \multicolumn{1}{c}{ Locality } & Elevation & Coordinate N & Coordinate E & Vegetation \\
\hline Bytíz & $529 \mathrm{~m}$ & $49^{\circ} 40^{\prime} 43^{\prime \prime}$ & $14^{\circ} 04^{\prime} 15^{\prime \prime}$ & Spruce \\
Červený křŕž & $400 \mathrm{~m}$ & $49^{\circ} 59^{\prime} 26^{\prime \prime}$ & $13^{\circ} 57^{\prime} 01^{\prime \prime}$ & Oak \\
Lhota u Př́bramě 1 & $487 \mathrm{~m}$ & $49^{\circ} 42^{\prime} 28^{\prime \prime}$ & $13^{\circ} 59^{\prime} 10^{\prime \prime}$ & Spruce \\
Lhota u Př́bramě 2 & $489 \mathrm{~m}$ & $49^{\circ} 42^{\prime} 28^{\prime \prime}$ & $13^{\circ} 59^{\prime} 09^{\prime \prime}$ & Spruce \\
\hline
\end{tabular}

were excavated down to the parent material in the intermediate part of the slope. Soil morphologies were described according to Jahn et al. (2006). The colours of individual soil horizons were decribed using Munsell Soil Color Charts (2000). The soil reference groups were classified based on the IUSS Working Group WRB (2015).

Thin sections of parent material were examined using the OLYMPUS BX51 polarizing microscope with the DP70 digital camera. Mineral compositions of powder samples of heavy minerals, parent material and clay fraction of soil samples were identify using $\mathrm{X}$-ray diffractometry. The size category of $0.125-$ $0.5 \mathrm{~mm}$ was used for the determination of heavy minerals in rocks. These minerals were separated using bromoform and methylene iodide (Ewing, 1931; Friedman and Sanders, 1978; Povondra and Ulrych, 1988). Clay fraction of soils for X-ray analysis was obtained using a sedimentation method. Prior this analysis, the samples were leached in $30 \% \mathrm{H}_{2} \mathrm{O}_{2}$, then rinsed with distilled water and mounted on oriented slides using the method of Jackson (1979). The minerals were identified in air-dried state, then solvated for 4 hours in ethylene glycol at $80{ }^{\circ} \mathrm{C}$ and heated to $550{ }^{\circ} \mathrm{C}$ for 4 hours. Individual spectra were obtained on the Philips PW 3710 diffractometer with $\mathrm{Cu}$ radiation (Červený kříž) and the Bruker D8 DISCOVER diffractometer with $\mathrm{Cu}$ radiation (Bytíz, Lhota u Př́bramě 1 and 2). X-ray patterns were recorded at a goniometric shift of $1^{\circ} \cdot \mathrm{min}^{-1}, 2 \Theta$. The diffractograms were interpreted using Joint Committee on Powder Diffraction Standards (1986). Semiquantitative values were calculated based on the height of individual mineral basal peaks using correction coefficients (Žigová and Št’astný, 2014).

Another analytical procedures for soil characteristics followed standard methods (van Reeuwijk, 2002; Pansu and Gautheyrou, 2006). Particle size distribution was determined using the pipette method. Texture classeses were determined according to Soil Survey Staff (2014). Soil pH in $\mathrm{H}_{2} \mathrm{O}$ and $1 \mathrm{M} \mathrm{KCl}$ was measured in 1:2.5 suspension with a SenTix21 electrode. These values were assessed using the scale of Baize (1993). Cation exchange capacity was determined using the method of Mehlich. The formula $(\mathrm{S} / \mathrm{CEC}) \times 100$, where $\mathrm{S}$ denotes the sum of exchangeable bases and CEC is cation exchange capacity, was used for the calculation of base saturation (in \%). Organic carbon was determined by wet combustion with a mixture of potassium dichromate and sulphuric acid and total nitrogen using the Kjeldahl method.

\section{RESULTS \\ PETROGRAPHY AND MINERALOGY OF ROCKS}

Parent material of the individual soil profiles was subjected to petrographic and mineralogical analyses.

The rock from the Bytíz site is granite (Fig. 6). In thin sections, the rock consists of quartz and muscovite. Plagioclase grains are hypidiomorphic and slightly lath-shaped, mostly clear, with lamellae. Quartz grains are clear, occasionally with muscovite inclusions. Quartz grains (ca. $5000 \mu \mathrm{m}$ in size) show no undulatory extinction and are slightly fractured. Muscovite occurs in flakes (ca. $1000 \mu \mathrm{m}$ in size) evenly distributed in the rock. They are altered and extinguish in parallel zones. A very fine ore pigment was observed around some flakes. The individual mineral grains are in tight contact, with no visible sutures. The following mineral composition of the rock was revealed by X-ray diffractometry: quartz, plagioclase, K-feldspar with a small admixture of chlorite, illite and amphibole. A high proportion of heavy minerals is represented by amphibole, magnetite and epidote in the magnetic fraction, and by zircon and apatite in the non-magnetic fraction.

The rock from the Červený kř́ž site is mudstone (Fig. 7). This rock shows massive texture with no signs of lamination. The predominant components in the thin section are quartz and clay minerals. Quartz grains (100 $\mu \mathrm{m}$ in size) are angular. Clay minerals are very fine, often impregnated with iron oxides. The matrix is also formed by quartz. The rock bears no fractures or distinct cracks. The following mineral composition of the rock was revealed by X-ray diffractometry: quartz, with a small amount of plagioclase, illlite, chlorite and kaolinite. The main component of magnetic fraction of heavy minerals is goethite with a small portion of hematite. Zircon occurs in the non-magnetic fraction.

The rock from the Lhota $u$ Př́bramě 1 site is greywacke (Fig. 8). The thin sections consist of quartz, muscovite and a fragment of siltstone. Matrix of the rock consists of abundant, more or less rounded detrital grains of quartz (mostly 200-300 $\mu \mathrm{m}$ in size) with very rugged surface. Plagioclase in the form of clear grains $(200 \mu \mathrm{m}$ in size $)$ with lamellae is less common. Flakes of detrital muscovite $(150 \mu \mathrm{m}$ in size $)$ show no visible alteration. The clasts are surrounded by clay minerals in very low amounts. The following 


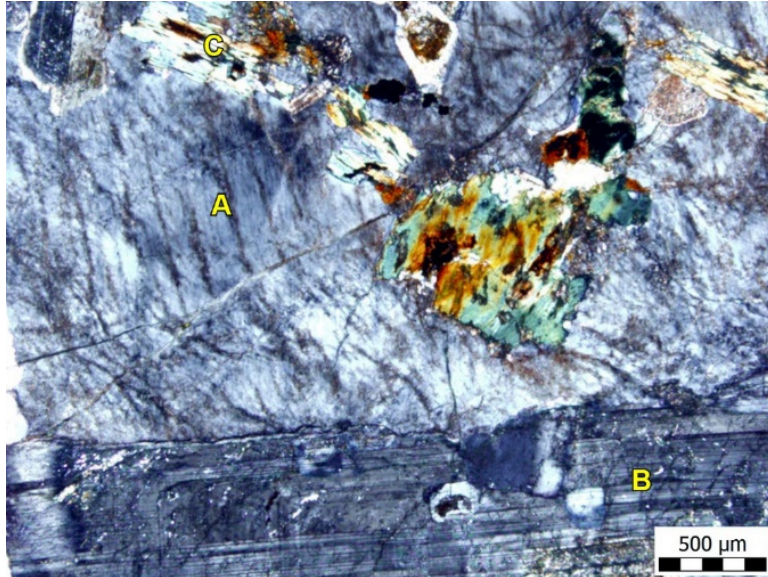

Fig. 6 A photomicrograph of a thin section of granite from the Bytíz site, crossed polars, A - quartz, B - plagioclase, C - muscovite (photo by A. Žigová and M. Št’astný).

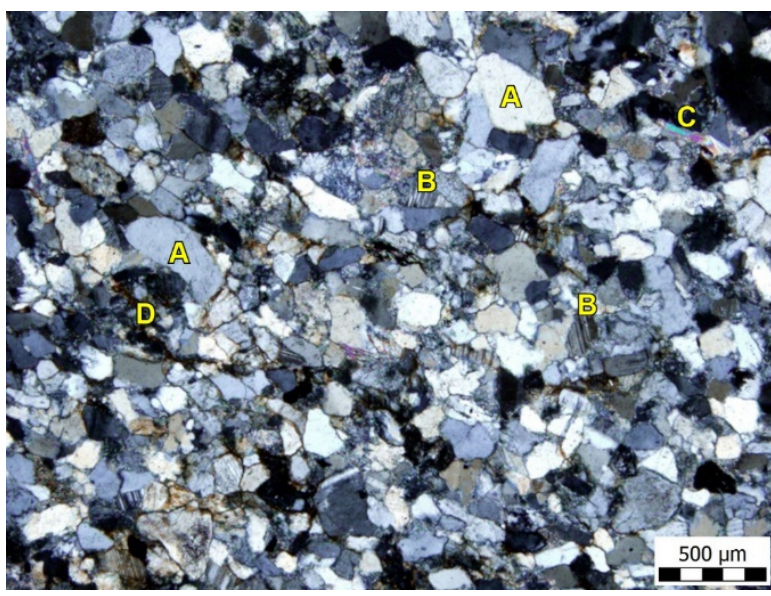

Fig. 8 A photomicrograph of a thin section of greywacke from the Lhota u Př́bramě 1 site, crossed polars A - quartz, B - plagioclase, C - muscovite, D - a fragment of siltstone (photo by A. Žigová and M. Št'astný).

mineral composition of the rock was revealed by $\mathrm{X}$-ray diffractometry: quartz and plagioclase predominate with small amounts of chlorite, illite, $\mathrm{K}$-feldspar and hematite. The main component of magnetic fraction of heavy minerals is hematite. Rutile and anatase are also present. Zircon is present in the non-magnetic fraction.

The rock from the Lhota u Príbramě 2 site is also greywacke (Fig. 9). The predominat component in thin sections is quartz (100-200 $\mu \mathrm{m}$ in size). The amounts of plagioclase and muscovite are lower. Detrital grains of quartz are partly angular and partly subrounded. Plagioclase $(200 \mu \mathrm{m}$ in size) occurs in the form of lamellar grains. The amount of detrital muscovite $(100 \mu \mathrm{m}$ in size) in the form of small flakes is accessory. The following mineral composition of the rock was revealed by X-ray diffractometry: quartz and plagioclase, with small amounts of chlorite, illite, $\mathrm{K}$-feldspar, and hematite in accessory amounts. The main component of magnetic fraction of heavy

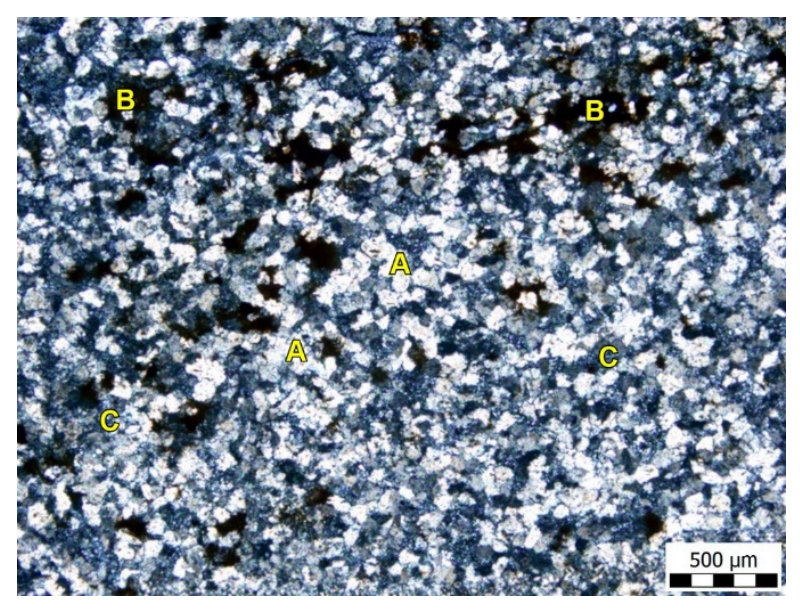

Fig. 7 A photomicrograph of a thin section of mudstone from the Červený krŕž site, crossed polars, A - quartz, B - iron oxides, C - clay minerals (photo by A. Žigová and M. Št’astný).

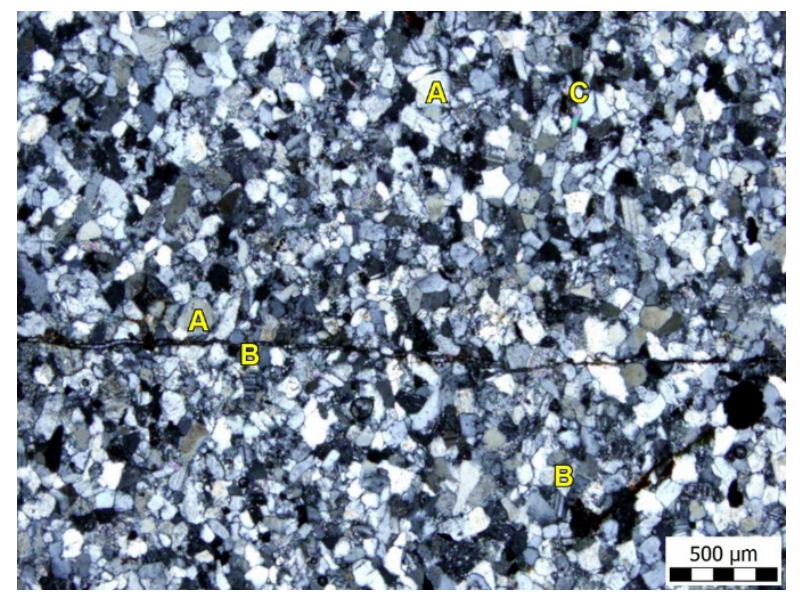

Fig. 9 A photomicrograph of a thin section of greywacke from the Lhota u Př́bramě 2 site, crossed polars, $\mathrm{A}$ - quartz, B - plagioclase, $\mathrm{C}$ - muscovite (photo by A. Žigová and M. Št'astný).

minerals is hematite. No heavy minerals were identified in the non-magnetic fraction due to the small particle size.

The individual rocks of the Brdská and Křivoklátská vrchovina Highlands differ in their mineral composition. Granite (Bytíz) is characterized by a high proportion of quartz and feldspar. High amount of quartz and an elevated content of clay minerals is typical for mudstone (Červený kř́ž). The greywacke from the Lhota u Príbramě 1 site is coarser-grained than that from the Lhota u Př́bramě 2 site. The identified association of heavy minerals corresponds to the type of the studied rocks. Highly stable zircon was determined in all rocks. Amphibole, epidote, magnetite and apatite also occur at the Bytíz site. Goethite and hematite, which are dispersed in the clay mass, are characteristic for the Červený kř́ž site. Rutile, anatase and hematite are typical for greywacke from the Lhota u Př́bramě 1 site. Hematite also occurs at the Lhota u Př́bramě 2 site. 
Table 2 Morphological characteristics of soils profiles.

\begin{tabular}{|c|c|c|c|c|c|c|c|c|}
\hline Locality & $\begin{array}{l}\text { Depth } \\
\text { cm }\end{array}$ & Horizon & $\begin{array}{l}\text { Colour } \\
\text { (moist) }\end{array}$ & Structure & $\begin{array}{c}\text { Rock fragments } \\
\%\end{array}$ & Consistence & Roots & $\overline{\text { Boundary }}$ \\
\hline \multirow{6}{*}{ Bytíz } & $0+1$ & $\mathrm{Oi}$ & $10 \mathrm{YR} 6 / 3$ & $\mathrm{~N}$ & $\mathrm{~N}$ & $\mathrm{LO}$ & VF & $\mathrm{A}$ \\
\hline & $+1+2$ & $\mathrm{Oe}$ & $10 Y R 3 / 4$ & MA & $\mathrm{N}$ & $\mathrm{LO}$ & VF & $\mathrm{C}$ \\
\hline & $+2+4$ & $\mathrm{Oa}$ & $10 Y R 2 / 2$ & PM & $\mathrm{N}$ & $\mathrm{LO}$ & VF & $\mathrm{C}$ \\
\hline & $0-5$ & $\mathrm{Ah}$ & $10 Y R 3 / 3$ & GR & 10 & VFR & $\mathrm{CO}$ & $\mathrm{C}$ \\
\hline & $5-22$ & $\mathrm{Bw}$ & $10 Y R 5 / 6$ & $\mathrm{AB}$ & 50 & FR & $\mathrm{F}$ & $\mathrm{G}$ \\
\hline & $22-60$ & $\mathrm{C}$ & 10 YR $6 / 6$ & $\mathrm{~N}$ & 70 & FR & $\mathrm{F}$ & \\
\hline \multirow{4}{*}{ Červený kř́íž } & $0-4$ & $\mathrm{Ah}$ & $10 \mathrm{YR} 2 / 2$ & GR & 10 & VFR & $\mathrm{CO}$ & $\mathrm{A}$ \\
\hline & $4-16$ & $\mathrm{AhBw}$ & $10 Y R 4 / 3$ & SB & 20 & FR & $\mathrm{CO}$ & $\mathrm{C}$ \\
\hline & $16-41$ & $\mathrm{Bw}$ & $10 Y R 5 / 4$ & $\mathrm{AB}$ & 60 & FR & $\mathrm{F}$ & $\mathrm{G}$ \\
\hline & $41-60$ & $\mathrm{C}$ & $10 Y R 6 / 4$ & $\mathrm{~N}$ & 90 & FR & $\mathrm{F}$ & \\
\hline \multirow{6}{*}{ Lhota u Příbramě 1} & $0+1$ & $\mathrm{Oi}$ & $10 Y R 4 / 3$ & $\mathrm{~N}$ & $\mathrm{~N}$ & $\mathrm{LO}$ & VF & $\mathrm{A}$ \\
\hline & $+1+7$ & $\mathrm{Oe}$ & 10YR 2/1 & MA & $\mathrm{N}$ & $\mathrm{LO}$ & VF & $\mathrm{C}$ \\
\hline & $+7+10$ & $\mathrm{Oa}$ & $10 Y R 2 / 2$ & PM & $\mathrm{N}$ & $\mathrm{LO}$ & VF & $\mathrm{C}$ \\
\hline & $0-17$ & $\mathrm{Ah}$ & $10 \mathrm{YR} 4 / 2$ & GR & 30 & VFR & $\mathrm{CO}$ & $\mathrm{C}$ \\
\hline & $17-37$ & $\mathrm{AhC}$ & $10 Y R 5 / 3$ & SB & 60 & FR & $\mathrm{F}$ & $\mathrm{G}$ \\
\hline & $37-51$ & $\mathrm{C}$ & $10 Y R 5 / 4$ & $\mathrm{~N}$ & 70 & FR & $\mathrm{F}$ & \\
\hline \multirow{5}{*}{ Lhota u Příbramě 2} & $0+1$ & $\mathrm{Oi}$ & $10 Y R 4 / 3$ & $\mathrm{~N}$ & $\mathrm{~N}$ & $\mathrm{LO}$ & VF & $\mathrm{A}$ \\
\hline & $+1+11$ & $\mathrm{Oe}$ & $10 Y R 2 / 1$ & MA & $\mathrm{N}$ & $\mathrm{LO}$ & VF & $\mathrm{C}$ \\
\hline & $+11+16$ & $\mathrm{Oa}$ & $10 \mathrm{YR} 2 / 2$ & PM & $\mathrm{N}$ & $\mathrm{LO}$ & VF & $\mathrm{C}$ \\
\hline & $0-10$ & $\mathrm{Ah}$ & $10 Y R 4 / 3$ & GR & 50 & VFR & $\mathrm{CO}$ & $\mathrm{G}$ \\
\hline & $10-20$ & $\mathrm{C}$ & 10 YR $5 / 3$ & $\mathrm{~N}$ & 70 & FR & $\mathrm{F}$ & \\
\hline
\end{tabular}

$\mathrm{N}$ - none, MA - massive, PM - porous massive, GR - granular, AB - angular blocky, SB - subangular blocky, LO - loose, VFR - very friable, FR - friable, CO - common, VF - few, F - few, A - abrupt, C - clear, G - gradual

\section{MORPHOLOGY OF SOILS}

Principal characteristics of soil profiles such as depth, Munsell colour (moist), structure, content of rock fragments, consistence horizon boundary and horizon designation are given in Table 2. Soil description serves as a basis for soil classification.

The $\mathrm{O}$ horizon was found to be missing only at the Červený křriž site which is covered by an oak forest. Other soil profiles developed in spruce forests show thicknesses of the $\mathrm{O}$ horizons from $4 \mathrm{~cm}$ (Bytíz) to $16 \mathrm{~cm}$ (Lhota u Př́ibramě 2). The $\mathrm{O}$ horizons are dominated by organic material consisting of undecomposed or partially decomposed litter and are of loose conistence. The $\mathrm{Oi}$ horizon consists of practically only undecomposed litter. No structure is present in these horizons. The Oe horizons are dominated by partly decomposed litter. The structure of these horizons is massive and not connected with pedogenetic ped formation. The Oa horizons contain more decomposed litter than the Oi horizon and a porous massive structure, which does not correspond to pedogenetic ped formation. All Ah horizons have granular structure formed by biotic assemble, and a very friable consistence. These horizons have higher thicknesses and higher contents of rock fragments at the Lhota u Prríbramě 1 and 2 sites.

The Bytíz and Červený kř́ž profiles display Bw horizons of different thicknesses, angular blocky structure and friable consistence.
The $\mathrm{C}$ horizon started at $22 \mathrm{~cm}$ at the Bytíz site, at $41 \mathrm{~cm}$ at the Červený kř́ž site, at $37 \mathrm{~cm}$ at the Lhota $\mathrm{u}$ Př́ibramě 1 site and at $10 \mathrm{~cm}$ at the Lhota u Př́bramě 2 site. The absence of soil structure in the $\mathrm{C}$ horizons is probably conected with the presence of relatively high amount of parent material.

The contents of rock fragments across profiles are specific for each site but generally increase down the profiles. The distribution and the diameter of roots in the soil profiles correspond to the type of vegetation.

Morphological analysis shows a different configuration of diagnostic horizons in the individual soil profiles.

\section{PARTICLE SIZE DISTRIBUTION}

The distributions of clay, silt and sand fraction in the individual soil profiles and texture classes are presented in Table 3 .

The results show differnces between the $\mathrm{O}$ horizon and other horizons of the soil profile in some cases. This is probably due to the character of this horizon that is dominated by undecomposed or partly decomposed organic matter poorly mixed with mineral components. The individual soil profiles show different distributions of clay, silt and sand fractions. The sand fraction with a relatively high amount of silt is typical for the Bytíz site with granite. Silt and sand fractions prevail in the profile at Červený kříž with 
Table 3 Particle size distribution of soils.

\begin{tabular}{lccccl}
\hline Locality & $\begin{array}{c}\text { Depth } \\
\text { (m }\end{array}$ & $\begin{array}{c}\text { Clay } \\
\text { \% }\end{array}$ & $\begin{array}{c}\text { Silt } \\
\text { \% }\end{array}$ & $\begin{array}{c}\text { Sand } \\
\text { \% }\end{array}$ & Texture class \\
\hline & $0+1$ & 26.5 & 35.6 & 37.9 & loam \\
& $+1+2$ & 25.0 & 58.6 & 16.4 & silt loam \\
Bytíz & $+2+4$ & 18.2 & 65.4 & 16.4 & silt loam \\
& $0-5$ & 13.1 & 36.2 & 50.7 & loam \\
& $5-22$ & 10.1 & 37.6 & 52.3 & sandy loam \\
& $22-60$ & 6.5 & 34.5 & 59.0 & sandy loam \\
\hline Červený kříž & $0-4$ & 16.7 & 52.9 & 30.4 & silt loam \\
& $4-16$ & 12.4 & 41.1 & 46.5 & loam \\
& $16-41$ & 17.7 & 37.4 & 44.9 & loam \\
& $41-60$ & 18.3 & 35.7 & 46.0 & loam \\
\hline \multirow{4}{*}{ Lhota u Pŕ́bramě 1} & $0+1$ & 22.0 & 58,7 & 19.3 & silt loam \\
& $+1+7$ & 21.1 & 57.4 & 21,5 & silt loam \\
& $+7+10$ & 11.3 & 57.2 & 31.5 & silt loam \\
& $0-17$ & 10.1 & 51.6 & 38.3 & silt loam \\
& $17-37$ & 12.2 & 54.3 & 33.5 & silt loam \\
& $37-51$ & 11.4 & 32.2 & 36.4 & silt loam \\
\hline
\end{tabular}

Clay $<0.002 \mathrm{~mm}$, silt $0.002-0.05 \mathrm{~mm}$, sand $0.05-2.00 \mathrm{~mm}$

mudstone. The silt fraction with a higher amount of sand was detected at the Lhota u Př́bramě 1 and 2 sites with greywacke.

The classification to texture classes follows from the ratios of clay, silt and sand fractions. The most characteristic texture classes are sandy loam (Bytíz), loam (Červený kříž) and silt loam (Lhota u Př́ibramě 1 and 2). The distribution of the texture classes is probably affected by the type of rock.

\section{CHEMICAL CHARACTERISTICS AND ORGANIC MATTER IN SOILS}

Data on chemical parameters and organic material are summarized in Table 4.

The values of $\mathrm{pH}$ are acid in the $\mathrm{O}$ horizons and very acid in the other horizons at the Bytíz soil profile. The soil profile at Červený Kříž displayed an acid reaction in the $\mathrm{Ah}$ and $\mathrm{AhBw}$ horizons and a weakly acid reaction in its lower part. The values of $\mathrm{pH}$ are practically the same at the sites of Lhota u Príbramé 1 and 2 . These soil profiles have a very acid reaction in the $\mathrm{Oi}$ and Oe horizons, a hyper acid one in the Oa and $\mathrm{Ah}$ horizons and a very acid one in the $\mathrm{C}$ horizons. The highest values of cation exchange capacity were found in the Oi horizons. The values of base saturation are mostly below $50 \%$ but show different values for the Ah horizons: $14 \%$ at Bytíz, $16 \%$ at Lhota u Př́ibramě $1,20 \%$ at Červený kříž and $24 \%$ at Lhota $\mathrm{u}$ Př́ibramě 2 . The base saturation in the $\mathrm{Bw}$ horizon is 34 \% (Bytíz) and 47 \% (Červený kř́íž).

The values of organic carbon are the highest in the $\mathrm{O}$ and $\mathrm{Ah}$ horizons but vary among individual soil profiles. The highest values of soil organic matter were identified at the Červený kř́ž site. A gradual reduction of total carbon and nitrogen contents with an increasing soil depth was found in the studied profiles. The $\mathrm{C} / \mathrm{N}$ value showed a variable enrichment of soil organic matter in nitrogen. This parameter in the Ah horizons reaches value from 9.67 (Lhota u Příbramě 1), 10.76 (Červený kříž) and 10.93 (Lhota u Př́ibramě 2) to 14.90 at Bytíz.

\section{MINERALOGY OF CLAY FRACTION SOILS}

Mineral compositions of the clay fraction of soils are given in Table 5. X-ray diffractograms are presented in Figure 10 (Bytíz), Figure 11 (Červený kříž), Figure 12 (Lhota u Př́bramě 1) and Figure 13 (Lhota u Př́ibramě 2).

The soil profile at the Bytíz site is characterized by prevalence of quartz (3.34 $\AA$ ), plagioclase $(3.19 \AA$ ) and K-feldspar (3.24 $\AA$ ). Amphiblole (8.41 $\AA$ ) is present in small amount. A high content of whewellite $(6.18 \AA)$ and accessory weddellite $(5.93 \AA)$ were detected in the Oi horizon. Palygorskite (10.5 $\AA$ ) was identified in the Oa horizon. Occurrence of gypsum

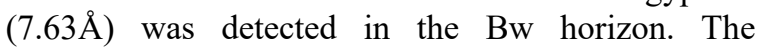
prevailing clay minerals in this soil are chlorite (14 a $7.05 \AA)$, illite (10 $\AA$ ) and kaolinite (7.15 $\AA)$. Smectite $(14.45 \AA$ in natural state and $15.71 \AA$ after glycol solvation) and mixed-layer illite-vermiculite structure (13.00 $\AA$ in natural state and $12.71 \AA$ after glycol solvation) occur as accessories in the $\mathrm{Ah}$ horizons. The amount of kaolinite increases continuously towards the parent material as a result of feldspar decomposition. 
Table 4 Chemical and organic matter characteristics of soils.

\begin{tabular}{|c|c|c|c|c|c|c|c|c|}
\hline Locality & $\begin{array}{c}\text { Depth } \\
\text { cm }\end{array}$ & $\mathrm{pH}_{\mathrm{H} 2 \mathrm{O}}$ & pH $\mathrm{KCl}$ & $\begin{array}{c}\text { CEC } \\
\text { cmol }^{\left(p^{+}\right)} \cdot \mathrm{kg}^{-1}\end{array}$ & $\begin{array}{l}\text { BS } \\
\% \\
\end{array}$ & $\begin{array}{l}\mathrm{C}_{\text {ox }} \\
\%\end{array}$ & $\begin{array}{l}N_{t} \\
\%\end{array}$ & $\mathbf{C} / \mathbf{N}$ \\
\hline \multirow{6}{*}{ Bytíz } & $0+1$ & 4.80 & 4.14 & 64.41 & 50 & 40.17 & 1.04 & 38.63 \\
\hline & $+1+2$ & 4.89 & 4.27 & 88.58 & 48 & 32.11 & 1.52 & 21.13 \\
\hline & $+2+4$ & 4.44 & 3.71 & 80.74 & 32 & 20.32 & 1.43 & 14.21 \\
\hline & $0-5$ & 3.67 & 2.86 & 28.66 & 14 & 4.62 & 0.31 & 14.90 \\
\hline & $5-22$ & 3.54 & 2.98 & 8.21 & 34 & 0.38 & 0.05 & 7.60 \\
\hline & $22-60$ & 3.91 & 2.89 & 7.58 & 24 & 0.12 & 0.05 & 2.40 \\
\hline \multirow{4}{*}{ Červený křŕž } & $0-4$ & 4.91 & 4.22 & 52.50 & 48 & 11.88 & 1.07 & 11.10 \\
\hline & $4-16$ & 4.73 & 3.57 & 21.16 & 20 & 2.26 & 0.21 & 10.76 \\
\hline & $16-41$ & 5.33 & 4.00 & 16.00 & 47 & 0.97 & 0.12 & 8.08 \\
\hline & $41-60$ & 5.32 & 3.86 & 13.80 & 36 & 0.69 & 0.09 & 7.67 \\
\hline \multirow{6}{*}{ Lhota u Př́ibramě 1} & $0+1$ & 4.02 & 3.06 & 54.69 & 53 & 38.80 & 1.58 & 24.57 \\
\hline & $+1+7$ & 3.19 & 2.62 & 67.48 & 24 & 32.88 & 2.00 & 16.44 \\
\hline & $+7+10$ & 3.04 & 2.61 & 45.11 & 14 & 17.12 & 0.95 & 18.02 \\
\hline & $0-17$ & 3.48 & 3.09 & 11.77 & 16 & 1.48 & 0.14 & 10.57 \\
\hline & $17-37$ & 4.08 & 3.35 & 7.63 & 40 & 0.58 & 0.06 & 9.67 \\
\hline & $37-51$ & 4.03 & 3.06 & 7.13 & 55 & 0.23 & 0.05 & 4.60 \\
\hline \multirow{5}{*}{ Lhota u Př́íbramě 2} & $0+1$ & 4.20 & 4.03 & 51.61 & 78 & 36.48 & 2.16 . & 16.86 \\
\hline & $+1+11$ & 3.37 & 3.28 & 66.05 & 43 & 35.96 & 1.52 & 23.69 \\
\hline & $+11+16$ & 3.00 & 2.54 & 70.41 & 16 & 14.64 & 1.07 & 13.68 \\
\hline & $0-10$ & 3.40 & 3.08 & 14.48 & 24 & 1.64 & 0.15 & 10.93 \\
\hline & $10-20$ & 3.64 & 3.23 & 8.54 & 32 & 0.60 & 0.06 & 12.67 \\
\hline
\end{tabular}

$\mathrm{CEC}-$ cation exchange capacity, $\mathrm{BS}-$ base saturation, $\mathrm{C}_{\mathrm{ox}}-$ organic carbon, $\mathrm{N}_{\mathrm{t}}-$ total nitrogen

Table 5 Mineralogy of the clay fraction of soils.

\begin{tabular}{|c|c|c|c|c|c|c|c|c|c|c|c|c|c|c|c|c|c|}
\hline Locality & $\begin{array}{c}\text { Depth } \\
\text { cm }\end{array}$ & $\begin{array}{l}\text { Ch } \\
\%\end{array}$ & $\begin{array}{c}\text { I } \\
\% \\
\end{array}$ & $\begin{array}{c}\text { I-V } \\
\% \\
\end{array}$ & $\begin{array}{l}\mathbf{K} \\
\% \\
\end{array}$ & $\begin{array}{c}\text { Sm } \\
\%\end{array}$ & $\begin{array}{l}\mathbf{Q} \\
\% \\
\end{array}$ & $\begin{array}{l}\text { Kf } \\
\% \\
\end{array}$ & $\begin{array}{l}\text { PI } \\
\% \\
\end{array}$ & $\begin{array}{c}\text { Am } \\
\%\end{array}$ & $\begin{array}{l}\text { Cp } \\
\% \\
\end{array}$ & $\begin{array}{c}\text { Gy } \\
\% \\
\end{array}$ & $\begin{array}{l}\text { Le } \\
\% \\
\end{array}$ & $\begin{array}{l}\text { Lu } \\
\%\end{array}$ & $\begin{array}{l}\mathrm{Pa} \\
\% \\
\end{array}$ & $\begin{array}{l}\text { We } \\
\% \\
\end{array}$ & $\begin{array}{c}\text { Wh } \\
\% \\
\end{array}$ \\
\hline \multirow{6}{*}{ Bytíz } & $0+1$ & 6 & 19 & 0 & 4 & 0 & 13 & 2 & 12 & 3 & 0 & 0 & 0 & 0 & 0 & 2 & 39 \\
\hline & $+1+2$ & 11 & 17 & 0 & 5 & 0 & 33 & 5 & 14 & 6 & 0 & 0 & 0 & 0 & 0 & 0 & 9 \\
\hline & $+2+4$ & 4 & 10 & 0 & 8 & 0 & 42 & 16 & 17 & 2 & 0 & 0 & 0 & 0 & 1 & 0 & 0 \\
\hline & $0-5$ & 4 & 3 & 4 & 9 & 2 & 53 & 10 & 15 & st & 0 & 0 & 0 & 0 & 0 & 0 & 0 \\
\hline & $5-22$ & 10 & 3 & 0 & 9 & 0 & 55 & 6 & 11 & 4 & 0 & 2 & 0 & 0 & 0 & 0 & 0 \\
\hline & $22-60$ & 7 & 11 & 0 & 11 & 0 & 54 & 6 & 10 & 1 & 0 & 0 & 0 & 0 & 0 & 0 & 0 \\
\hline \multirow{4}{*}{ Červený kříž } & $0-4$ & 21 & 12 & 0 & 8 & 0 & 47 & 0 & 10 & 0 & 0 & 0 & 2 & 0 & 0 & 0 & 0 \\
\hline & $4-16$ & 46 & 13 & 0 & 0 & 0 & 28 & 5 & 6 & 0 & 0 & 2 & 0 & 0 & 0 & 0 & 0 \\
\hline & $16-41$ & 60 & 17 & 0 & 0 & 0 & 23 & 0 & 0 & 0 & 0 & 0 & 0 & 0 & 0 & 0 & 0 \\
\hline & $41-60$ & 53 & 14 & 0 & 0 & 0 & 26 & 0 & 0 & 0 & 0 & 7 & 0 & 0 & 0 & 0 & 0 \\
\hline \multirow{6}{*}{ Lhota u Příbramě 1} & $0+1$ & 12 & 24 & 0 & 6 & 0 & 18 & 0 & 6 & 0 & 0 & 0 & 0 & 0 & 0 & 0 & 34 \\
\hline & $+1+7$ & 2 & 3 & 0 & 2 & 0 & 18 & 13 & 15 & 0 & 9 & 0 & 36 & 2 & 0 & 0 & 0 \\
\hline & $+7+10$ & 2 & 4 & 0 & 2 & 0 & 34 & 17 & 27 & 0 & 0 & 0 & 0 & 1 & 0 & 13 & 0 \\
\hline & $0-17$ & 9 & 11 & 6 & 10 & 0 & 51 & 7 & 7 & 0 & 0 & 0 & 0 & 0 & 0 & 0 & 0 \\
\hline & $17-37$ & 10 & 9 & 1 & 10 & 0 & 57 & 5 & 8 & 0 & 0 & 0 & 0 & 0 & 0 & 0 & 0 \\
\hline & $37-51$ & 7 & 9 & 0 & 8 & 0 & 55 & 11 & 10 & 0 & 0 & 0 & 0 & 0 & 0 & 0 & 0 \\
\hline \multirow{5}{*}{ Lhota u Příbramě 2} & $0+1$ & 5 & 8 & 0 & 3 & 0 & 16 & 2 & 7 & 0 & 0 & 0 & 0 & 0 & 0 & 0 & 59 \\
\hline & $+1+11$ & 7 & 13 & 0 & 5 & 0 & 30 & 5 & 13 & 2 & 0 & 0 & 0 & 0 & 0 & 0 & 25 \\
\hline & $+11+16$ & 4 & 10 & 2 & 5 & 0 & 31 & 16 & 20 & 0 & 0 & 0 & 0 & 1 & 0 & 11 & 0 \\
\hline & $0-10$ & 6 & 7 & 1 & 6 & 1 & 46 & 16 & 16 & 1 & 0 & 0 & 0 & 0 & 0 & 0 & 0 \\
\hline & $10-20$ & 10 & 7 & 0 & 6 & 0 & 53 & 9 & 13 & 0 & 0 & 2 & 0 & 0 & 0 & 0 & 0 \\
\hline
\end{tabular}

$\mathrm{Ch}$ - chlorite, I - illite, I-V - illite-vermiculite, K - kaolinite, Sm - smectite, Q - quartz, Kf - K-feldspar, Pl - plagioclase, $\mathrm{Am}$ - amphibole, $\mathrm{Cp}$ - calciocopiapite, Gy - gypsum, Le - lepidocrocite, Lu - ludlockite, $\mathrm{Pa}$ - palygorskite, We - weddellite, $\mathrm{Wh}$ - whewellite 


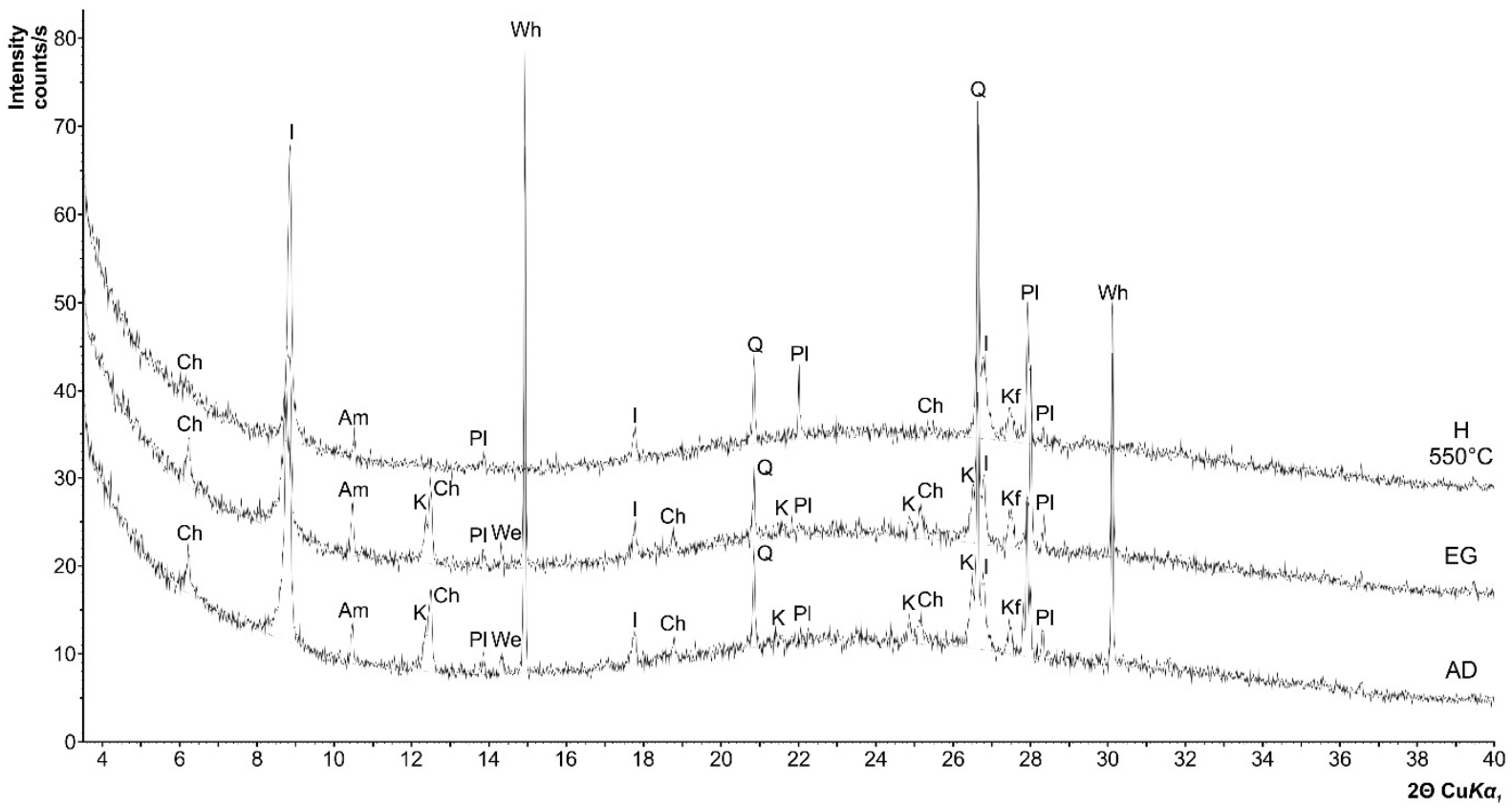

Fig. 10 X-ray diffraction patterns of clay fraction from $0+1 \mathrm{~cm}$ at Bytíz, AD - air-dried, EG - ethylene-glycol solvated, $\mathrm{H}$ - after heating, $\mathrm{Ch}$ - chlorite, I - illite, $\mathrm{K}$ - kaolinite, $\mathrm{Kf}-\mathrm{K}$-feldspar, $\mathrm{Pl}$ - plagioclase, $\mathrm{Q}-$ quartz, $\mathrm{Am}$ - amphibole, $\mathrm{We}$ - weddellite, $\mathrm{Wh}$ - whewellite.

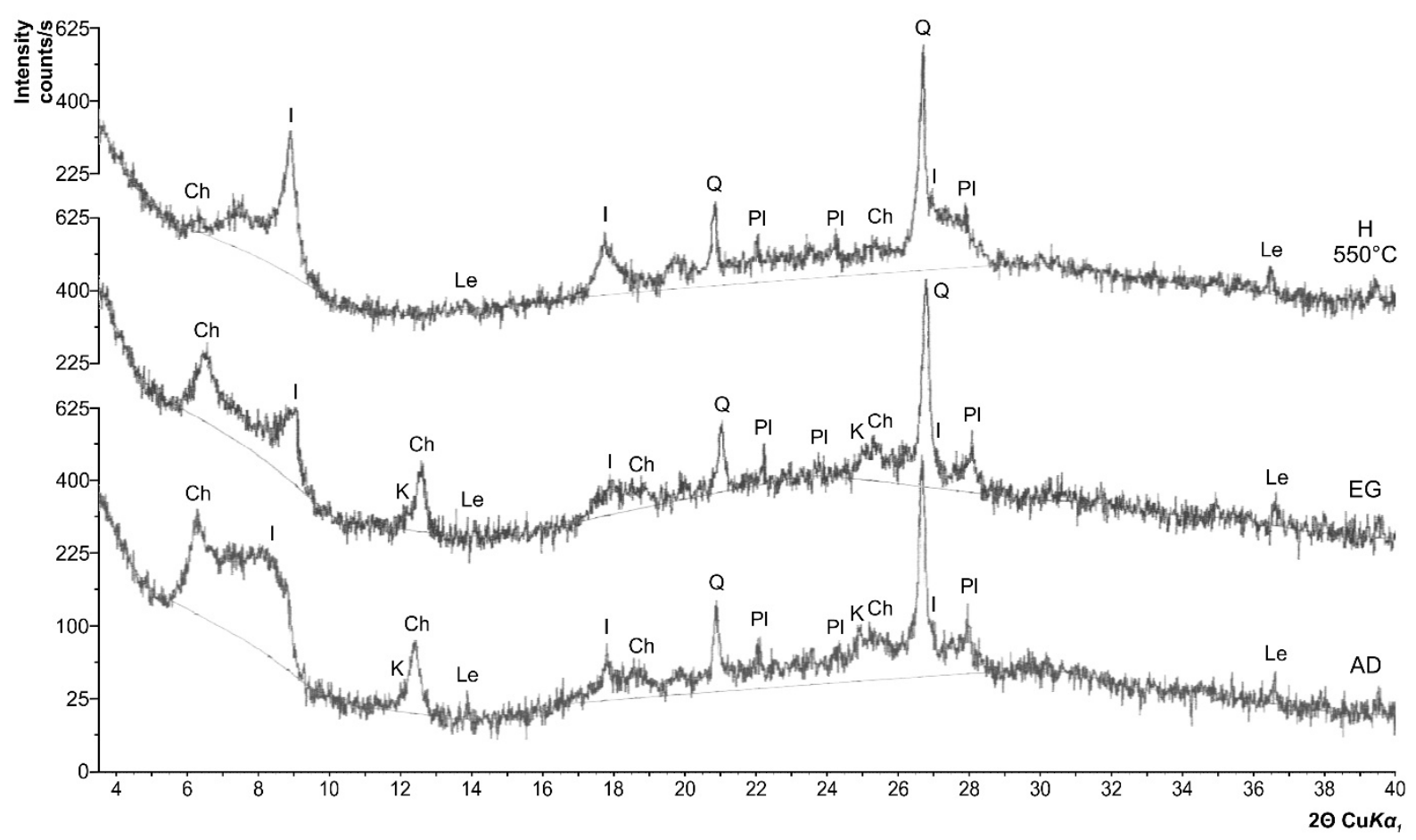

Fig. 11 X-ray diffraction patterns of clay fraction from $0+1 \mathrm{~cm}$ at Červený kř̌ž, AD - air-dried, EG - ethylene-glycol solvated, $\mathrm{H}$ - after heating, $\mathrm{Ch}$ - chlorite, I - illite, $\mathrm{K}$ - kaolinite, $\mathrm{Pl}$ - plagioclase, $\mathrm{Q}$ - quartz, Le - lepidocrocite. 


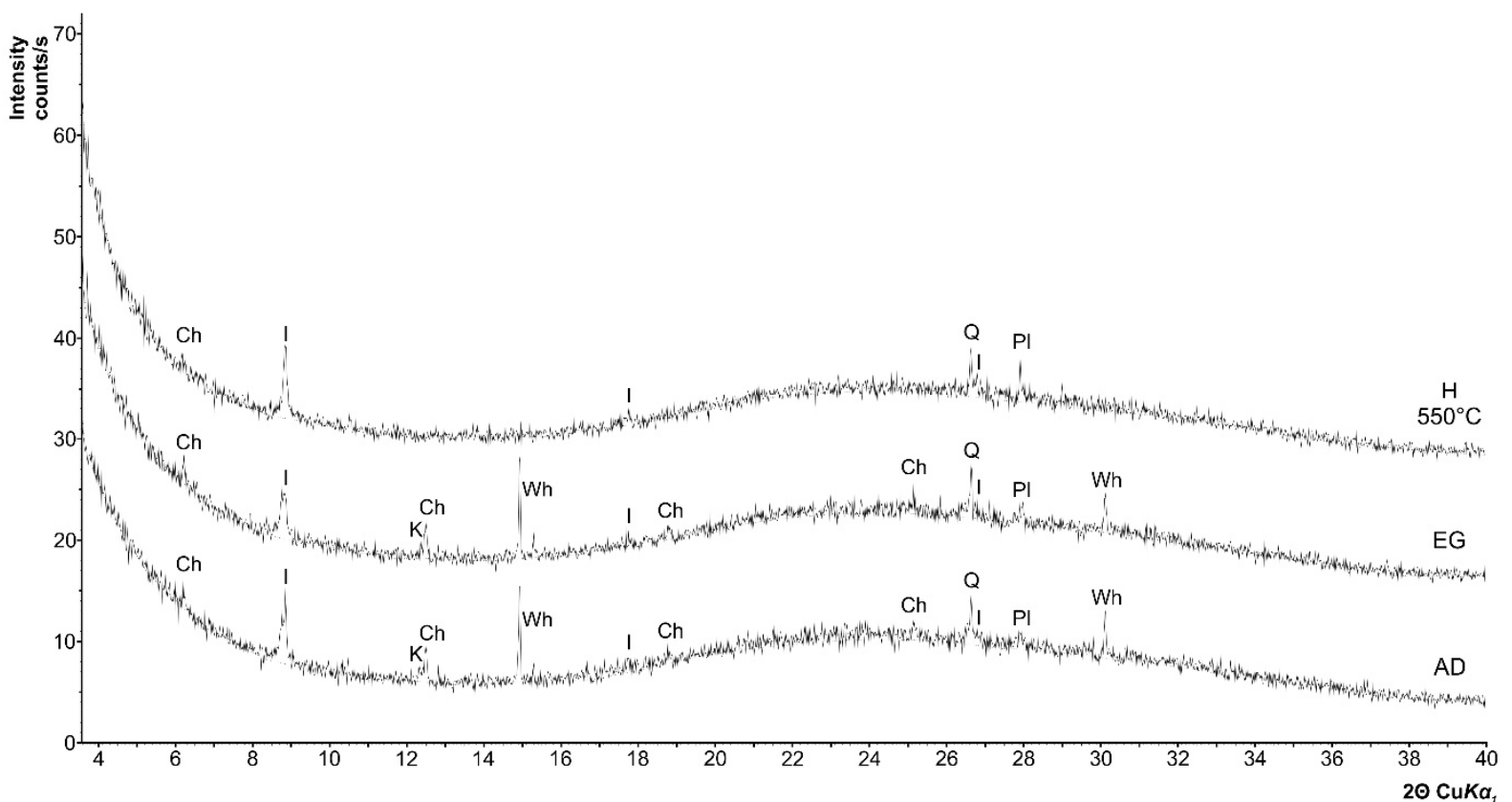

Fig. 12 X-ray diffraction patterns of clay fraction from $0+1 \mathrm{~cm}$ at Lhota u Př́bramě $1, A D$ - air-dried, EG - ethylene-glycol solvated, $\mathrm{H}$ - after heating, $\mathrm{Ch}$ - chlorite, I - illite, $\mathrm{K}$ - kaolinite, Pl - plagioclase, $\mathrm{Q}$ - quartz, Wh - whewellite.

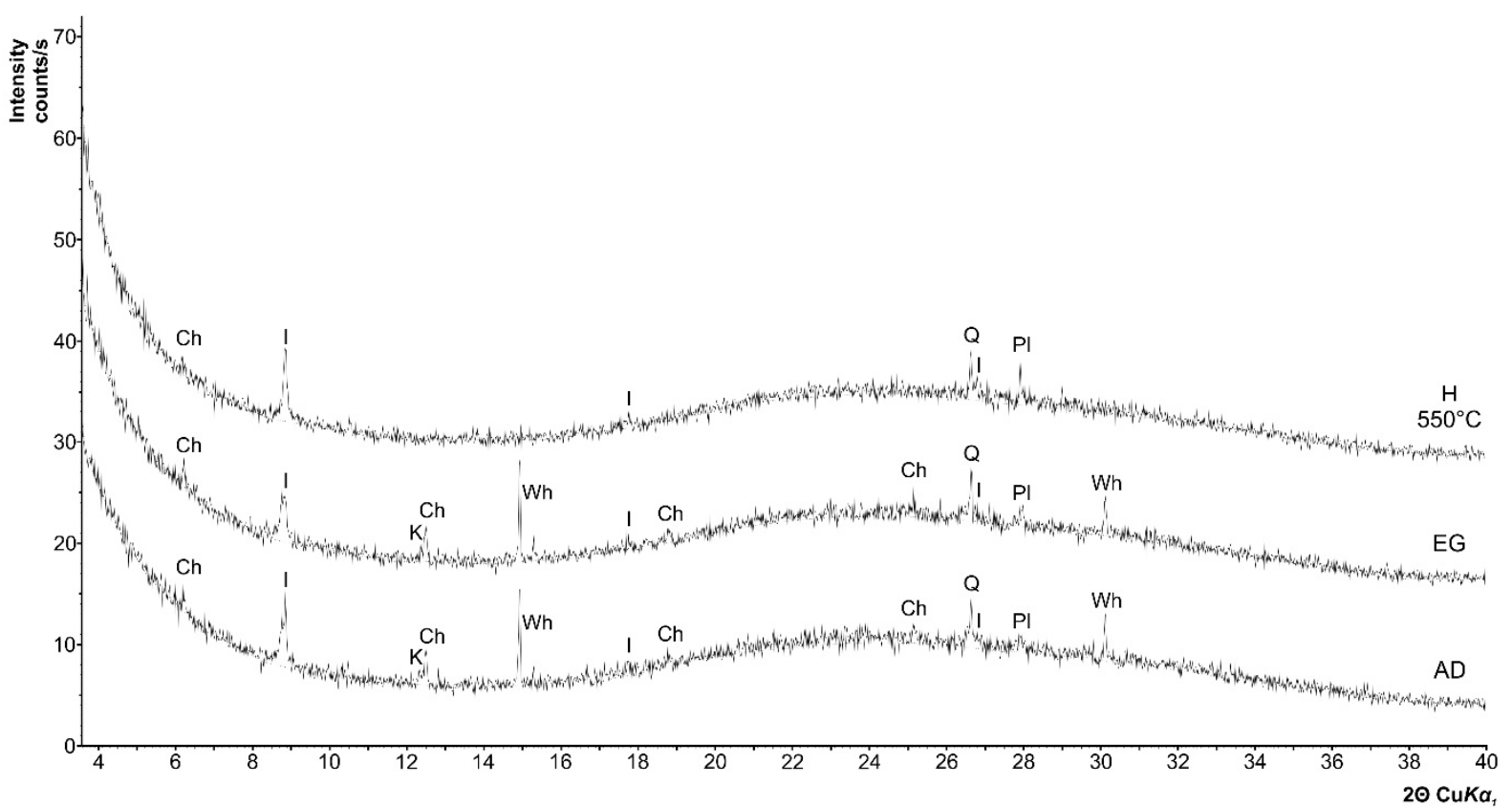

Fig. 13 X-ray diffraction patterns of clay fraction from $0+1 \mathrm{~cm}$ at Lhota u Př́bramě $2, A D$ - air-dried, $\mathrm{EG}$ - ethylene-glycol solvated, $\mathrm{H}$ - after heating, $\mathrm{Ch}$ - chlorite, I - illite, $\mathrm{K}$ - kaolinite, $\mathrm{Kf}$ - K-feldspar, $\mathrm{Pl}$ - plagioclase, Q - quartz, Wh - whewellite. 
The soil profile at the Červený kř́ž site has a relatively low quatz content. Plagioclase and $\mathrm{K}$ - feldspar are present in its upper part. Gypsum and lepidocrocite $(6.26 \AA)$ contents are low. The dominant component are clay minerals dominated by chlorite and partly illite. Kaolinite occurs only in the Ah horizon. Chlorite content is the highest in the Bw horizon.

The soil profile at Lhota u Př́bramě 1 containns mainly quartz, plagioclase and K-feldspar. High contents of whewellite are typical for the Oi horizon.

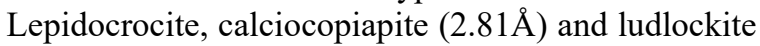
$(8.81 \AA)$ were identified in the Oe horizon. A relatively high content of weddellite and also a small amount of ludlockite were documented in the $\mathrm{Oa}$ horizon. Chlorite, illite and kaolinite are represented in the association of clay minerals. The mixed-layer illite-vermiculite structure occurs in accessory amounts in the $\mathrm{AhC}$ and $\mathrm{C}$ horizons.

The soil profile at Lhota u Prríbramě 2 is also characterized by the predominance of quartz, plagioclase and K-feldspar. Amphibole and gypsum are present in accessory amounts. The proportion of whewellite is high in the $\mathrm{Oi}$ and Oe horizons. Ludlockite and a relatively high amount of weddellite occur in the Oa horizon. Chlorite, illite and kaolinite were identified among clay minerals, with local presence of smectite and of illite-vermiculite structure.

The mineral composition of clay fraction in the individual horizons of soils profiles differs mainly in the contents of quartz, plagioclase, K-feldspar, amphibole and in the proportion of clay minerals. A higher proportion of illite and kaolinite is typical for the Bytíz site. The highest proportion of clay minerals was identified at the Červený kř́ž site, being dominated by chlorite and illite. The soil profile at Lhota u Prríbramě 1 shows a higher content of clay minerals than Lhota u Príbramě 2. The ratios of chlorite, illite and kaolinites are practically the same at these two localities.

\section{DISCUSSION}

The intensity of modern pedogenesis in the territory of Brdská and Křivoklátská vrchovina Highlands was studied in the condition of moderately warm climate in the intermediate part of slopes on different silicate Proterozoic and Paleozoic rocks. The character of the parent material is a base line that must be known for the evaluation of individual stages of pedogenesis. As indicated by petrographic and mineralogical analyses, granite and mudstone have more favourable ratios of individual minerals for a higher intensity of pedogenesis than greywacke. In the case of granite (Bytíz), this is the ratio between quartz and feldspar. A favourable ratio between quartz and clay minerals was found for mudstone (Červený kříž).

The architecture of WRB classification (IUSS Working Group WRB, 2015) comprises two levels of categorical detail. Morpholological analysis, especially the total thicknees of profiles, structure and content of rock fragments, shows that all soil sequences at the first level belong to the refernce group of Leptosols. The second level consists of principal and supplementary qualifiers which allow a more detailed description of pedogenesis. This level of classification of soils combines morphological and analytical parameters. Certain differences lie in the presence of the cambic horizon, the content of rock fragments, texture classes, and base saturation. The soil sequences developed on granite (Bytíz) and mudstone (Červený kř́ž) were classified as Cambic Leptosols (Dystric, Skeletic). The soil profiles where parent material is greywacke (Lhota u Př́bramě 1 and Lhota u Př́bramě 2) were classified as Dystric Leptosols (Skeletic).

The $\mathrm{pH}$ values and base saturation indicate that the soil development on greywacke takes place in more acid conditions than on granite and mudstone.

Individual pedogenic proceses are indicated by soil diagnostic horizons. Litter formation is connected with the occurrence of $\mathrm{O}$ horizon. The presence of $\mathrm{Ah}$ horizons corresponds to the process of humification. The process of transformation of soil material in situ is characteristic for the Bw horizon.

The presence of $\mathrm{O}$ horizons was identified at sites covered with a spruce forest. These horizons are absent from the Červený kř́ž site where the main source of biomass is oak. Zagyvai-Kiss et al. (2019) reported that the litter mass and water holding capacity reach higher values in spruce forests than in oak forests. Consequently, it can be assumed that the oak forests provide a more favourable condition for faster transformation from the $\mathrm{O}$ horizon to the A horizon.

The occurrence of Ah horizon was documented at all studied sites. Basic qualitative parameters of this process, such as organic carbon, total nitrogen and the $\mathrm{C} / \mathrm{N}$ ratio show some differncies among the individual sites. This is probably caused by spatial variation in soil mineralogy as indicated by the results of Torn et al. (1997).

The presence of $\mathrm{Bw}$ horizon was confirmed at the Bytíz site (granite) and the Červený kříž site (mudstone) in similar $\mathrm{pH}$ conditions. The intensity of this proces is higher in soils developed on mudstone. Compared to granite, this parent material has a more favourable mineral composition and also the quarz/clay minerals ratio, rendering a higher intensity of pedogenesis.

The development of chlorite from the weathering products is a characteristic process of the clay mineral formation in Cambic Leptosols (Dystric, Skeletic) developed on mudstone (Červený kř́ǐz). The amount of illite is lower, and kaolite is present only in the Ah horizon. The process of clay mineral formation in Cambic Leptosols (Dystric, Skeletic) developed on granite has a different character. Such soil profiles are dominated by clay minerals such as chlorite, illite and kaolinite. Smectite and mixed layer illite-vermiculite structure occur as accessories in the Ah horizons. Some differences in the mineral composition of soils developed on granite were described by Sirový (1974) 
from the Čistá site. These differences are probably due to the local composition of granite. Granite from Čistá belongs to the Krušné hory pluton while granite from Bytíz belongs to the Central Bohemian pluton.

The amount of clay minerals in Dystric Leptosols (Skeletic) is lower than that in Cambic Leptosols (Dystric, Skeletic). Chlorite, illite and kaolinite are practically equally represented in the Dystric Leptosol (Skeletic). Smectite and illite-vermiculite structure occur locally. Soils developed on greywacke contain mainly quartz, plagioclase and K-feldspar.

Weddellite and whewellite were found in relatively large amounts in the $\mathrm{O}$ horizons of soil profiles with the exception of the Červený kríž site, probably for the first time in the Czech Republic. A characteristic feature of sites with the occurrences of these minerals is the presence of fungi. Data on the occurrence of fungi were obtained for Bytíz (Kubrová et al., 2014) and Lhota u Př́íbramě (Cejpková et al., 2016). The identified mineral phases whewellite $\mathrm{Ca}\left(\mathrm{C}_{2} \mathrm{O}_{4}\right) \cdot 2 \mathrm{H}_{2} \mathrm{O}$ and weddellite $\mathrm{Ca}\left(\mathrm{C}_{2} \mathrm{O}_{4}\right) \cdot\left(\mathrm{H}_{2} \mathrm{O}\right)$ are organogenic minerals. According to Graustein et al. (1977), the occurrence of these minerals in the $\mathrm{O}$ and A horizons of different soils indicates that calcium oxalates are the major metabolic product of fungi in the natural environment. Some aspects of the origin of whewellite and weddellite were described by Curlík and Kolesár (2014) and Uren (2018). Dauer and Perakis (2014) reported the presence of calcium oxalate minerals in temperate forest ecosystems, existing in live and decomposing biomass pools, as well as in organic and mineral soil horizons, which corresponds with the findigs from the Bytíz and Lhota $\mathrm{u}$ Př́bramě sites. The predominat from of calcium oxalate minerals at these sites is whewellite. Weddellite occurs in small amounts, which is probably due to its lower stability.

Palygorskite was identified in a small portion of the $\mathrm{O}$ horizon at the Bytíz site. An autochthonous origin of palygorskite in soils has been reported from eastern Saudi Arabia (Shadfan and Masshady, 1985), northwestern China (Xie et al., 2013) and South Africa (Francis et al., 2020). An allochthonous origin of this mineral in soils is also possible Bain (1997). The possibility of modern central European soils being influenced by Saharan dust was also documented by Š́ly (1981). Data on the influence of modern and ancient Saharan dust on the development of soils was published by Varga et al. (2016) and Varga (2020). The above mentioned facts rather suggest an allochthonous origin of palygorskite in the $\mathrm{O}$ horizon of soil developed on granite.

Minerals such as ludlockite and calciocopiapite occur in accessory amounts in the $\mathrm{O}$ horizons at the Lhota u Príbramě 1 and 2 sites. The question is the source of these minerals. No information on the presence of ludlockite and calciocopiapite in soils is available. Their presence in the $\mathrm{O}$ horizons is probably due to eolian transport from the surrounding heaps which were studied by Suchara and Sucharová (2004) and Sucharová and Suchara (2004).

\section{CONCLUSIONS}

Modern pedogenesis in the territory of the Brdská and Křivoklátská vrchovina Highlands was studied in the condition of moderately warm climate in the intermediate part of slopes on silicate rocks of Proterozoic and Paleozoic age.

Morpholological analysis of soils showed that all studied sequences belong to the reference group of Leptosols. More detailed analyses combining morphological and analytical parameters allow to determine the soils developed on mudstone and granite as Cambic Leptosols (Dystric, Skeletic) and the soils developed on greywacke as Dystric Leptosols (Skeletic).

The intensity of soil development on individual parent materials decreases in the order: mudstone (Ah-AhBw-Bw-C)>granite (Oi-Oe-Oa-Ah-Bw-C)> greywacke 1 (Oi-Oe-Oa-Ah-AhC-C)>greywacke 2 (Oi-Oe-Oa-Ah-C). The configuration of diagnostic horizons of individual soil sequences indicates some differences in the intensity of pedogenesis. Soil profile development is more intensive in Cambic Leptosols (Dystric, Skeletic) than in Dystric Leptosols (Skeletic).

The process of humification is present at all study sites. Evidence of pedogenetic alteration is characteristic for soils developed on granite and mudstone.

The $\mathrm{pH}$ and base saturation values indicate that the soil development on greywacke takes place in more acid conditions than on granite and mudstone. Granite and mudstone have more favourable ratios of individual minerals, which results in a higher intensity of pedogenesis on these partent rocks than on greywacke.

The highest intensity of pedogenesis was observed in Cambic Leptosols (Dystric, Skeletic) on mudstone, which are dominated by clay minerals, especially chlorite and illite.

Organogenic minerals such as weddellite and whewellite were found in relatively high amounts in $\mathrm{O}$ horizons of soil profiles with the exception of the Červený kríž site. This is probably their first record in soils in the Czech Republic.

\section{ACKNOWLEDGMENTS}

The research was conducted within institutional support RVO 67985831 of the Institute of Geology of the Czech Academy of Sciences.

\section{REFERENCES}

Bain, D.C. and Tait, J.M.: 1977, Mineralogy and origin of dust fall on skye. Clay Minerals, 12, No. 4, 353-355. DOI: 10.1180/claymin. 1977.012.4.08

Baize, D.: 1993, Soil Science Analyses. A Guide to Current Use. John Wiley and Sons. 192 pp. 
Bína, J. and Demek, J.: 2012, From lowland to the mountains. Geomorphological units of the Czech Republic. Academia, Praha, 343 pp., (in Czech).

Chaloupský, J., Chlupáč, I., Mašek, J., Waldhausrová, J. and Cháb, J.: 1995, Stratigraphy. In: Dallmeyer, R.D., Franke, W. and Weber, K. (Eds.): Pre-Permian Geology of Central and Eastern Europe. Springer Berlin Heidelberg, 379-381.

Cejpková, J., Gryndler, M., Hršelová, H., Kotrba, P., Řanda, Z., Synková, I. and Borovička, J.: 2016, Bioaccumulation of heavy metals, metalloids, and chlorine in ectomycorrhizae from smelter-polluted area. Environ. Pollut., 218, 176-185. DOI: 10.1016/j.envpol.2016.08.009

Chlupáć, I., Brzobohatý, R., Kovanda, J. and Stráník, Z.: 2002, Geological history of the Czech Republic. Academia, Praha. 436 pp., (in Czech).

Čurlík, J. and Kolesár, M.: 2014, Inorganic carbon sequestration in authigenic carbonates and their distribution in loessic soils: some micromorphological aspects. Acta Geol. Slovaka, 6, No. 2, 191-202, (in Slovak).

Dauer, J.M. and Perakis, S.S.: 2014, Calcium oxalate contribution to calcium cycling in forests of contrasting nutrient status. For. Ecol. Manag., 334, 64-73. DOI: 10.1016/j.foreco.2014.08.029

Ewing, C.J.C.: 1931, A comparison of the methods of heavy mineral separation. Geol. Mag., 68, No. 3, 136-140. DOI: $10.1017 / \mathrm{S} 0016756800095509$

Francis, M.L., Majodina, T.O. and Clarke, C.E.: 2020, A geographic expression of the sepiolite-palygorskite continuum in soils of northwest South Africa. Geoderma, 379, 114615.

DOI: 10.1016/j.geoderma.2020.114615

Franke, W.: 2000, The mid-European segment of the Variscides: tectonostratigraphic units, terrane boundaries and plate tectonic evolution. In: Franke, W., Haak, W., Oncken, O., and Tanner, D. (Eds.) Orogenic processes: Quatification and modelling in the Variscan Belt. Geol. Soc. Spec. Publ., 179. London, Bath. 35-63.

Friedman, G.M. and Sanders, J.E.: 1978, Principles of sedimentology. John Wiley and Sons, New York, $792 \mathrm{pp}$.

Graustein, W.C., Cromack, K. and Sollins, P.: 1977, Calcium Oxalate: Occurrence in Soils and Effect on nutrient and geochemical cycles. Science, 198, No. 4323, 1252-1254.

DOI: $10.1126 /$ science. 198.4323 .1252

Hajná, J., Žák, J. and Kachlík, V.: 2011, Structure and stratigraphy of the Teplá-Barrandian Neoproterozoic, Bohemian Massif: A new platetectonic reinterpretation. Gondwana Research, 19, No. 2, 495-508. DOI: 10.1016/j.gr.2010.08.003

IUSS Working Group WRB: 2015, World Reference Base for Soil Resources 2014, update 2015, International soil classification system for naming soils and creating legends for soil maps. World Soil Resources Reports, 106, FAO, Rome, 192 pp.

Jackson, M.L.: 1979, Soil chemical analyses - advanced course. Madison, Wisconsin, 895 pp.

Jahn, R., Blume, H.P., Asio, V.B., Spaargaren, O. and Schad, P.: 2006, Guidelines for soil description. Fourth edition. FAO, Rome, 97 pp.
Joint Committee on Powder Diffraction Standards: 1986, Mineral powder diffraction file: Data book, Swarthmore, Pennsylvania, $1186 \mathrm{pp}$.

Kachlík, V. and Chlupáč, I.: 2001, Basics of Geology. Karolinum, Praha, 342 pp., (in Czech).

Kubrová, J., Žigová, A., Řanda, Z., Rohovec, J., Gryndler, M., Krausová, I. and Borovička, J.: 2014, On the possible role of macrofungi in biogeochemical fate of uranium in polluted forest soils. J. Hazard. Mater., 280, 79-88. DOI: 10.1016/j.jhazmat.2014.07.050

Lessovaia, S.N. and Polekhovsky, Yu.S.: 2009, Mineralogical composition of shallow soils on basic and ultrabasic rocks of east Fenoscandia and of the Ural Mountains, Russia. Clays Clays Miner., 57, No. 4, 476-485. DOI: 10.1346/CCMN.2009.0570408

Loba, A., Sykula, M, Kierczak, J., Labaz, B., Bogacz, A. and Waroszwski, J.: 2020, In situ weathering of rocks or aeolian silt deposition: key parameters for verifying parent material and pedogenesis in the Opawskie Mountains - a case study from SW Poland. J. Soils and Sediments, 20, No. 1, 435-451. DOI: $10.1007 / \mathrm{s} 11368-019-02377-5$

Malkovský, M.: 1979, Tectogeny of the platform cover of the Bohemian Massif. Academia, Praha, 176 pp., (in Czech).

Marvis, C., Egli, M., Plötze, M., Blum, J.D. and Mirabella, A.: 2010, Initial stages of weathering and soil formation in the Morteratsch proglacial area (Upper Engadine, Switzerland). Geoderma, 155, No. 3-4, 359-371. DOI: 10.1016/j.geoderma.2009.12.019

Mašek, J.: 2000, Stratigraphy of the Proterozoic of the Barrandian area. Bull. Geosci., 75, No. 3, 197-200.

Munsell Soil Color Charts: 2000, Revised Washable Edition. Munsell Color, GretagMacbeth, New Winsdor, $10 \mathrm{pp}$.

Němeček, J. and Tomášek, M.: 1983, Geography of Czechoslovak soils. Studie ČSAV, 23, Academia, Praha. 100 pp., (in Czech).

Pansu, M. and Gautheyrou, J.: 2006, Handbook of Soil Analysis: Mineralogical, Organic and Inorganic Methods. Springer, Berlin-Heidelberg, 993 pp.

Povondra, P. and Ulrych, J.: 1988, Fundamentals of mineral processing and separation. Státní pedagogické nakladatelství Praha, 105 pp., (in Czech).

Quitt, E.: 1971, Climatic regions of Czechoslovakia. Studia Geographica, 16, Československá akademie věd, Geografický ústav, Brno, 82 pp., (in Czech).

Śály, R. and Mihálik, A.: 1981, Saharan dust over the territory of Slovakia. Čas. Miner. Geol., 26, No. 3, 285-293, (in Slovak).

Shadfan, H. and Mashhady, A.S.: 1985, Distribution of palygorskite in sediments and soils of Eastern Saudi Arabia. Soil Sci. Soc. Am. J.1, 49, No. 1, 243-250. DOI: $10.2136 /$ sssaj 1985.03615995004900010050x

Sirový, V.: 1974, Clay mineral formation and alteration in some brown forest soils. Rostlinná výroba, 20, No. $5,451-459$.

Soil Survey Staff: 2014, Keys to Soil Taxonomy, 12th edition. USDA-Natural Resources Conservation Service, Washington DC, $360 \mathrm{pp}$.

Suchara, I. and Sucharová, J.: 2004, Distribution of 36 element deposition rates in a historic mining and smelting area as determined through fine-scale biomonitoring techniques. Part II: Relative long- 
term accumulated atmospheric deposition levels. Water Air Soil Pollut., 153, No. 1-4, 229-252. DOI: 10.1023/B:WATE.0000019915.70739.bf

Sucharová, J. and Suchara, I.: 2004, Distribution of 36 element deposition rates in a historic mining and smelting area as determined through fine-scale biomonitoring techniques. Part I: Relative and absolute current atmospheric deposition levels detected by moss analyses. Water Air Soil Pollut., 153, No. 1-4, 205-228.

DOI: 10.1023/B:WATE.0000019944.33209.83

Targulian, V.O. and Krasilnikov, P.V.: 2007, Soil system and pedogenic processes: Self-organization, time scales, and environmental significance. Catena, 71, No. 3, 373-381. DOI 10.1016/j.catena.2007.03.007

Torn, M.S., Trumbore, S.E., Chadwick, O.A., Vitousek, P.M. and Hendricks, D.M.: 1997, Mineral control of soil organic carbon storage and turnover. Nature, 389, No. 6647, 170-173. DOI: 10.1038/38260

Uren, N.C.: 2018, Calcium oxalate in soils, its origins and fate - a review. Soil Res., 56, No. 5, 443-450. DOI: $10.1071 /$ SR17244

van Reeuwijk, L.P.: 2002, Procedures for soil analysis. Technical paper, 9. International Soil Reference and Information Centre. Wageningen, $97 \mathrm{pp}$.

Varga, G.: 2020, Changing nature of Saharan dust deposition in the Carpathian Basin (Central Europe): 40 years of identified North African dust events (1979-2018). Environ. Int., 139, 105712. DOI: 10.1016/j.envint.2020.105712

Varga, G., Cserhati, C., Kovacs, J. and. Szalai, Z.: 2016, Saharan dust deposition in the Carpathian Basin and its possible effects on interglacial soil formation. Aeolian Res., 22, 1-12. DOI: 10.1016/j.aeolia.2016.05.004

Vorel, T. and Stárková, M.: 2011, Geological mapping a tool for obtaining knowledge of geological evolution in the Krrivoklátsko Protected Landscape Area. Bohem. Cent., 31, 21-32, (in Czech).
Waren, C.R.: 2017, Changes in small organic N during early stages of soil development. Soil Biol. Biochem., 110, 44-55. DOI: 10.1016/j.soilbio.2017.03.004

Weber, J., Tyszka, R., Kocowicz, A., Szadorski, J., Debicka, M. and Jamroz, E.: 2012, Mineral composition of the clay fraction of soils derived from granitoids of the Sudetes and Fore-Sudetic Block, southwest Poland. Eur. J. Soil Sci., 63, No. 5, 762-772. DOI: $10.1111 / \mathrm{j} .1365-2389.2012 .01482 . \mathrm{x}$

West, J.A., Galy, A, and Bickle, M.: 2005, Tectonic and climatic controls on silicate weathering. Earth Planet. Sci. Lett., 235, No. 1-2, 211-228. DOI: 10.1016/j.epsl.2005.03.020

Xie, Q.O., Chen, T.H., Zhou, H., Xu, X.C., Xu, X.F., Ji, J.F., Lu, H.Y. and Balsam, W.: 2013, Mechanism of palygorskite formation in the Red Clay Formation on the Chinese Loess Plateau, northwest China. Geoderma, 192, 39-49. DOI: 10.1016/j.geoderma.2012.07.021

Zagyvai-Kiss, K.A., Kalicz, P., Szilágyi, J. and Gribovszki, Z.: 2019, On the specific water holding capacity of litter for three forest ecosystems in the eastern foothills of the Alps. Agric. For. Meteorol., 278, 107656. DOI: $10.1016 /$ j.agrformet.2019.107656

Žigová, A. and Št’astný, M.: 2014: Pedogenesis on volcanic rocks in protected landscape areas in Central and North Bohemia. Soil Water Res., 9, No. 4, 153-160. DOI: 10.17221/23/2014-SWR 